\title{
Identification of Herding Behavior, Overconfidence and Risk Tolerance Based on Gender Perspective on Stock Investors in Aceh
}

\author{
Zaida Rizqi Zainul ${ }^{1, *}$ Irma Suryani $^{1}$ \\ ${ }^{1}$ Department of Management, Universitas Syiah Kuala, Banda Aceh, Indonesia \\ "Corresponding author. Email: zaida_rizqi@unsyiah.ac.id
}

\begin{abstract}
This study aims to compare herding behavior and risk tolerance between male and female investors in Aceh. The primary data used in this study was collected using questionnaires. The population in this study are investors in Aceh Province, Indonesia with a total sample of 386 respondents. The analytical method used was the Mann Whitney U test. The results show that: 1) There is a difference in risk tolerance between male and female investors in Aceh, 2) There is no difference in overconfidence between male and female investors in Aceh 3) There is a difference herding behaviour between male and female investors in Aceh. Also, advances in information technology, education level, knowledge make gender differences no longer a limitation for investors to feel more confident and brave in making investment decisions. This study is expected to enrich the financial management literature on investor behaviour, increase the number of capital market investors in Aceh through an investor behaviour approach, and a reference for implementing a long-term strategy in determining the capital market regulator in Aceh.
\end{abstract}

Keywords: Behavioral finance, Capital markets, Herding, Overconfidence, Risk tolerance.

\section{INTRODUCTION}

Investment decisions are not only based on the estimates of the prospects of investment instruments, but also on the psychological factors in considering investment decisions. In fact, according to observations from various parties, it is stated that the psychological factors of investors have the biggest role in investing. These psychological factors ultimately affect investment activities and the results.

To make investment decisions in the capital market, every investor has different choices and different levels of risk taking. Differences in behaviour among investors in investment decisions are often inconsistent. Of course, in responding to various alternatives, they must have various characteristics to lead to diverse decision solutions. Moreover, differences in behaviour are also caused by the fact that the capital market consists of people with characters that influence their investing decisions. Their differences are including their expectations, knowledge and experiences. This often creates behavioural bias in the capital market with expectations and preferences of investors tend to differ between investors [1].
In every investment decision-making, including to any group an investor (educated or not, experienced or not, male or female, young or old, big or small investors) he or she must involve emotions in the investment decision-making process [2]. The bias in investor behaviour is often detrimental to investors. They may take wrong decisions by simply prioritizing emotions rather than ratios in making investment decisions. In addition, because some investors have a high level of confidence, they also tend to act without a complete information which potentially risk their investments. Their ability to predict the market is not necessarily the case because the market is strongly influenced by various forms of behavioural bias.

There are several behavioural biases of investors in the capital market that focus on the behaviour of the capital market in Indonesia, namely risk tolerance and herding. All these behaviors often come to beginner investors who have just entered the capital market due to lack of experience and investment knowledge and are affected by market rumors that often confuse them. This condition has an impact on an action called selfdeception behaviour (self-deception). Self-deceptive behaviour occurs because investors have self-confidence 
which usually overestimates their knowledge and information accuracy, but ignores other available information, giving rise to the perception that investors have above average abilities. This fact shows that overconfidence behaviour results in biased and inaccurate decisions [3].

Female decision-making is more risk-averse than male decision-making, which is evident in their choice of professions that have an impact on their income, investment decisions and products to be purchased[4]. Women are described as individuals who are not very independent, emotional, illogical, difficult to make decisions, lack self-confidence and desperately need a sense of security. On the other hand, men are independent individuals, not too emotional, very logical, easy to make decisions, very confident and do not really need a sense of security.

The development of globalization and the economy has caused capital market investment to get more and more attention from various circles of society, both women and men. So far, capital market investment is seen as one of the solutions that can help the country's economy. With the capital market, companies can obtain alternative funding that is cheaper than through banking. So it is hoped that the existence of the capital market can increase economic development, one of which is the freedom of the country from the problem of poverty and unemployment because indirectly companies that have large business scales can also absorb workers. Therefore, the appeal from the government to intensify capital market investment activities is getting stronger day by day.

In order to increase the number of investors in Aceh, the Indonesia Stock Exchange (IDX) continues to make efforts to socialize and educate the capital market. Judging from the population of Aceh which reaches more than 5 million people, but in this province the number of stock investors is still relatively very small, which is only around 4.000 people with the number of transactions reaching Rp 600 billion (Preliminary Interview with Aceh IDX Representative, Mr. Thasrif Muhadi). This study chose the research location in Aceh because of several reasons. Based on the explanation stated above, this study wants to examine more deeply about the behavioural comparison analysis between male and female investors in Aceh.

\section{LITERATURE REVIEW HYPOTHESIS DEVELOPMENT}

\subsection{Gender dan Herding Behavior}

An investor's tendency to follow the lead of other investors is known as herding. Emotional deviations can result from herding, according to a behavioral perspective. Because herding provides investors with useful and reliable information, investors prefer to engage in herding. Sheer numbers of institutional and private investors have been found to herd [5]; [6]. In addition, research shows that herding behavior is prevalent among investors who are less confident [7]. Female investors display herding behavior because they are less confident than male investors. Only a few empirical studies have shown that female investors, particularly in emerging markets, tend to mimic the actions of other investors when making investment decisions, especially in emerging markets [8]. Based on the literature review and previous research that has been stated above, the hypothesis of this study is as follows:

$\mathrm{H}_{1}$ : There are differences in herding behavior between male and female investors.

\subsection{Gender and Risk Tolerance}

Tolerance for discomfort while risking one's current wealth for the sake of future growth is known as one's risk tolerance. [9]. Female stock investors are also found to have a lower tolerance for risk than their male counterparts, according to empirical evidence [10]. Due to women's risk-averse behavior, they value risk stocks higher than men's assessments of stocks, therefore women rarely trade their stocks [11]; [12]. Differences in risk tolerance between developed and developing markets are influenced by the genders [13]. The result found that male investors were willing to take more risk than female investors. Based on the literature review and previous research that has been stated above, the hypothesis of this study is as follows:

$\mathrm{H}_{2}$ : There is a difference in risk tolerance between male and female investors.

\subsection{Gender dan Overconfidence}

According to [14], the indicators of overconfidence are having experience confidence in the success of an investment plan, having confidence in your abilities above other investors, trusting your own investment opinions more than others, and having confidence in predicting stocks and assuming losses due to external factors. For those investors who prefer a high degree of uncertainty, they'll be much more likely to engage in stock investments [15] Thus, investors become irrational and engage in risky and excessive trading. Their portfolio returns are negatively impacted and their trading performance suffers as a result of this [16]. In addition, investors who prefer risk are more likely to exhibit overconfident behaviour [15] and participate more in stock investments. Many studies on gender differences in investment confidence in emerging markets, including the Arab region, support the findings in developed markets. In particular, studies from Pakistan [15]; Jordan [17] and Saudi Arabia [18] found that male investors were more confident and traded more stocks than female 
investors. Based on the literature review and previous research that has been stated above, the hypothesis of this study is as follows:

$\mathrm{H}_{3}$ : There is a difference in overconfidence between male and female investors.

\section{METHOD}

The population of this research is investors who live in Aceh, 10,800 people (www.idx.co.id). Sampling in this study used the probability sample (probability sampling). The type of sampling used is simple random sampling. Based on the Slovin formula, the number of samples obtained is 385.7, which is rounded up to 386 stock investors in Aceh. Data were collected using a questionnaire circulated online via google forms and some were directly distributed to investors. The questionnaire asked the respondent's data (demographic factors), and questions about the level of risk tolerance, overconfidence level, and herding behavior. Questionnaires were presented in multiple-choice questions, each with scale 1 to 5 . The higher the weight obtained, the higher the level of risk tolerance, level of overconfidence, and herding behavior.

In this study the types and sources of data used were primary and secondary data. Primary data was data obtained by researchers directly through questionnaires to find out information about risk tolerance, overconfidence and herding behavior. While secondary data was research data obtained by researchers indirectly and through intermediary media such as: 1) Libraries, in the form of theoretical books that support calculations and analysis, 2) website www.idx.co.id, 3) www.ojk.go.id and other media sites.

SPSS for Windows is used to perform data analysis and a non-parametric test in this study (Mann-Whitney $\mathrm{U})$. Overall, nonparametric tests were applied to analyse data when the results do not follow a normal distribution, such as when the results are ordinal or ranking variables [19]. Non-parametric tests were used because the data were not normally distributed and were collected using a likert scale. There were two groups of men and women in this study, and the Mann-Whitney test was used to identify gender differences in investment behavior (risk tolerance, overconfidence and herding behavior). Operational variables in this study are risk tolerance, overconfidence and herding behavior. Indicators of risk tolerance were adapted from [14] and [20]. Indicators of overconfidence are adapted from [14]. Furthermore, Indicator herding was adapted from [14], [5].

\section{RESULTS \& DISCUSSION}

\subsection{Respondents Characteristic}

Based on Table 1 it is showed that respondents characteristics. Most of the respondents were male with 249 respondents or $64.5 \%$. Furthermore, there were 137 female respondents or $35.5 \%$ of the total sample.

\subsection{Validity Test Result}

Validity testing was conducted to determine the level of validity of the instrument (questionnaire) used in collecting the data obtained. A questionnaire is said to be valid if the questions and questionnaires are able to reveal something measured by the questionnaires. This test was performed using Bivariate Pearson correlation (Pearson Product Moment). The minimum requirement that is considered valid is the value of $r=0.3$ [21]. The following are the results of validity testing for the variables risk tolerance, overconfidence and herding. Based on Table 2 shows that test results of all questions to measure the risk tolerance, overconfidence and herding variables, the results of the $r$ value are above 0.3 , which means that all indicators of each variable are valid.

\subsection{Reliability Test Result}

The test results are said to be reliable if the Cronbach's Alpha value is higher than 0.60. Meanwhile, if the value of Cronbach's Alpha lower than 0.60, then the test results are said to be unreliable or inconsistent. Based on Table 3 shows the results of the reliability test, it shows that the Cronbach's Alpha value > 0.60 for all question items used to measure the risk tolerance, overconfidence and herding. This indicates that all variables are reliable.

\subsection{Hypothesis Testing}

The Mann-Whitney U Test was used to analyze the research data and test the three main hypotheses. To compare the difference between two independent groups when the dependent variable is continuous or ordinal, the Mann-Whitney U Test is a popular non-parametric test. Mann-test Whitney's is more powerful than the t-test unless the data are non-normally dispersed [22].

Overall, the Mann-Whitney test is stronger than the ttest unless the data are normally distributed [22]. MannWhitney tests are used to identify gender differences in investment behavior (risk tolerance, overconfidence, and herding behavior), where gender is an independent variable with two groups of men and women. 
Table 1. Characteristics of Respondents

\begin{tabular}{|c|c|c|}
\hline Characteristics & Number & $\%$ \\
\hline \multicolumn{3}{|l|}{ Gender } \\
\hline Male & 249 & 64.5 \\
\hline Female & 137 & 35.5 \\
\hline Total & 386 & $100 \%$ \\
\hline Age & 33 & 85 \\
\hline Under 19 years & 33 & 8.5 \\
\hline 20-29 years & 141 & 36.5 \\
\hline 30-39 years & 116 & 30.1 \\
\hline 40-49 years & 70 & 18.1 \\
\hline 50 years & 26 & 6.7 \\
\hline Total & 386 & 100 \\
\hline \multicolumn{3}{|l|}{ Marriage Status } \\
\hline Married & 186 & $51,8 \%$ \\
\hline Single & 200 & $48,2 \%$ \\
\hline Total & 386 & $100 \%$ \\
\hline \multicolumn{3}{|l|}{ Income } \\
\hline$\leq$ Rp.5.000.000 & 165 & 42.7 \\
\hline Rp.5.000.000 - Rp.10.000.000 & 153 & 39.7 \\
\hline Rp.10.000.000 - Rp.15.000.000 & 34 & 8.8 \\
\hline$>$ Rp.15.000.000 & 34 & 8.8 \\
\hline Total & 386 & 100 \\
\hline \multicolumn{3}{|l|}{ Education level } \\
\hline High School & 98 & $25,4 \%$ \\
\hline Diploma (D1/D2/D3) & 9 & $2,3 \%$ \\
\hline Bachelor (S1) & 143 & $37 \%$ \\
\hline Magister & 101 & $26,2 \%$ \\
\hline $\mathrm{PhD}$ & 35 & $9,1 \%$ \\
\hline Total & 386 & $100 \%$ \\
\hline \multicolumn{3}{|l|}{ Working Status } \\
\hline Civil Servant & 120 & 31 \\
\hline State-owned enterprises & 8 & 2.1 \\
\hline Non-Government Lectures & 8 & 2.1 \\
\hline State-owned enterprises staffs & 8 & 2.1 \\
\hline Non-Government staffs & 60 & 15.5 \\
\hline College students & 115 & 29.8 \\
\hline Entrepreneurs & 59 & 15.3 \\
\hline others & 8 & 2,1 \\
\hline Total & 386 & 100 \\
\hline
\end{tabular}


Table 2. Results of Testing the Validity of Risk Tolerance Variables

\begin{tabular}{|c|c|c|c|c|}
\hline No & Variable & Questions & $\begin{array}{l}\text { Total Item } \\
\text { Correlation }\end{array}$ & Note \\
\hline \multirow{6}{*}{1} & \multirow{6}{*}{ Risk Tolerance } & $\begin{array}{l}\text { I dare to make investment decisions when the information I get } \\
\text { is relevant }\end{array}$ & 0.897 & Valid \\
\hline & & $\begin{array}{l}\text { When I invest, I am more concerned with the rate of return } \\
\text { (return) than the risk factor }\end{array}$ & 0.833 & Valid \\
\hline & & $\begin{array}{l}\text { I prefer high risk investments with high returns over low risk } \\
\text { investments with low returns }\end{array}$ & 0.851 & Valid \\
\hline & & $\begin{array}{l}\text { I do not consider risk in investing as a situation to be avoided at } \\
\text { all costs }\end{array}$ & 0.946 & Valid \\
\hline & & $\begin{array}{l}\text { I prefer investing in stocks over investing in deposits or mutual } \\
\text { funds }\end{array}$ & 0.909 & Valid \\
\hline & & $\begin{array}{l}\text { The amount of my investment in the capital market is greater than } \\
\text { the investment in a bank account }\end{array}$ & 0.90 & Valid \\
\hline \multirow{5}{*}{2} & \multirow{5}{*}{ Overconfidence } & When I make an investment plan, I believe it will be successful & 0.892 & Valid \\
\hline & & I always believe that I will correctly predict stock price movements & 0.868 & Valid \\
\hline & & I can identify stocks that will profit in the market in the future & 0.761 & Valid \\
\hline & & $\begin{array}{l}\text { When I buy a stock and get a return, I think it is because of my } \\
\text { knowledge and financial ability }\end{array}$ & 0.816 & Valid \\
\hline & & $\begin{array}{l}\text { I believe that the experience of investment losses are mainly due } \\
\text { to external factors beyond my control (such as the financial crisis) }\end{array}$ & 0.737 & Valid \\
\hline \multirow{7}{*}{3} & \multirow{7}{*}{$\begin{array}{l}\text { Herding } \\
\text { Behavior }\end{array}$} & $\begin{array}{l}\text { I trust more in the opinions of financial analysts, friends, and } \\
\text { family members compared to my own investment opinions }\end{array}$ & 0.805 & Valid \\
\hline & & $\begin{array}{l}\text { When I want to invest, I depend on other people's investment } \\
\text { decisions }\end{array}$ & 0.833 & Valid \\
\hline & & $\begin{array}{l}\text { When investing in stocks, I follow the recommendations of } \\
\text { friends, colleagues, or close relatives }\end{array}$ & 0.800 & Valid \\
\hline & & I react quickly to changes in other investors' decisions & 0.846 & Valid \\
\hline & & $\begin{array}{l}\text { I prefer to buy shares if there are a lot of shares that have been } \\
\text { ordered since the beginning of trading }\end{array}$ & 0.817 & Valid \\
\hline & & $\begin{array}{l}\text { If in the last month the overall trading volume on the stock market } \\
\text { was higher than usual, I would increase the amount of my stock } \\
\text { market holdings }\end{array}$ & 0.810 & Valid \\
\hline & & $\begin{array}{l}\text { I see that foreign investors have better investment performance } \\
\text { than domestic investors }\end{array}$ & 0.819 & Valid \\
\hline
\end{tabular}

Table 3. Reliability Test Results

\begin{tabular}{|l|c|c|c|c|}
\multirow{2}{*}{\multicolumn{1}{c|}{ Variable }} & \multirow{2}{*}{ Number of item } & \multicolumn{2}{c|}{ Cronbach's Alpha } & \multirow{2}{*}{ Note } \\
\cline { 3 - 5 } & & Test & Standard & \\
\hline Risk Tolerance & 7 & 0,813 & 0,6 & Reliable \\
\hline Overconfidence & 6 & 0,810 & 0,6 & Reliable \\
\hline Herding & 8 & 0,796 & 0,6 & Reliable \\
\hline
\end{tabular}


Table 4. Mann-Whitney U Test Results for Risk Tolerance, Overconfidence and Herding

\begin{tabular}{|l|c|c|c|}
\hline & TTR & TOV & THR \\
\hline Mann-Whitney U & 14118.000 & 16913.000 & 12884.500 \\
\hline Wilcoxon W & 23571.000 & 48038.000 & 44009.500 \\
\hline Z & -2.824 & -.139 & -4.015 \\
\hline Asymp. Sig. (2-tailed) & .005 & .890 & .000 \\
\hline
\end{tabular}

a. Grouping Variable: Gender

Table 5. Test Results Mean Ranks Variables Risk Tolerance, Overconvidence and Herding Behavior

\begin{tabular}{|l|l|c|c|c|}
\hline \multicolumn{1}{c}{ Variable } & \multicolumn{1}{|c|}{ Gender } & N & Mean Rank & Sum of Ranks \\
\hline \multirow{4}{*}{ Risk Tolerance } & Male & 249 & 205.30 & 51120.00 \\
\cline { 2 - 5 } & Female & 137 & 172.05 & 23571.00 \\
\cline { 2 - 5 } & Total & 386 & & \\
\hline \multirow{3}{*}{ Overconfidence } & Male & 249 & 192.92 & 48038.00 \\
\cline { 2 - 5 } & Female & 137 & 194.55 & 26653.00 \\
\cline { 2 - 5 } & Total & 386 & & 44009.50 \\
\hline \multirow{3}{*}{ Herding } & Male & 249 & 176.74 & 30681.50 \\
\cline { 2 - 5 } & Female & 137 & 223.95 & \\
\cline { 2 - 5 } & Total & 386 & & \\
\hline
\end{tabular}

The basis for making the decision on the Man-Whitney $\mathrm{U}$ test is if the value of Asymp.Sig. (2-tailed) $<0.05$ then the hypothesis is accepted, and vice versa if the value of Asymp.Sig. (2-tailed) $>0.05$ then the hypothesis is rejected.

Based on the test results in the Table 4, they show that $\mathrm{U}$ value for risk tolerance (TTR) variable is 14,118 and $\mathrm{W}$ value is 23,571 . When converted to a $\mathrm{Z}$ value, the amount is -2.824 . Significant value or $\mathrm{P}$ Value of $0.005<$ 0.05 . This shows that $\mathrm{H} 0$ is rejected and $\mathrm{H} 1$ is accepted, which means that there is a significant difference in risk tolerance for men and women in Aceh. U value for overconfidence (TOV) variable is 16,913 and $\mathrm{W}$ value is 48,038 . When converted to a $\mathrm{Z}$ value, the amount is 0.139 . Significant value or $P$ Value of $0.890>0.05$. This shows that $\mathrm{Ho}$ is accepted and $\mathrm{H} 2$ is rejected, which means that there is no significant difference in overconfidence of men and women in Aceh. $U$ value for herding (THR) variable is $12,884.5$ and $\mathrm{W}$ value is $44,009.5$. When converted to a $\mathrm{Z}$ value, the amount is 4.015. Significant value or $\mathrm{P}$ Value of $0.000<0.05$. This shows that $\mathrm{Ho}$ is rejected and $\mathrm{H} 3$ is accepted, which means that there is a significant difference in overconfidence of men and women in Aceh.

\subsection{Discussion}

Based on the results of data processing, it shows that $\mathrm{H} 0$ is rejected and $\mathrm{H} 1$ is accepted, which means that there is a significant difference in risk tolerance for men and women in Aceh. Based on the results of data processing in Table 5, they show that the risk tolerance variable produces a mean rank value for men of 205.30 while the mean rank for women is 205.30 . This shows that the risk tolerance in men is greater than in women. The level of risk tolerance in men is higher because of the high optimism and masculine traits possessed by men. This makes them more daring to invest in riskier stocks because they expect a higher rate of return. Meanwhile the results of the study show that women in Aceh have a lower level of risk tolerance because on average women in Aceh prefer to invest in stocks with lower fluctuations or whose stock price movements tend to be more stable. In addition, female investors in Aceh also tend to prefer to invest in fixed assets such as gold and time deposits with lower variance and volatility, even though the rate of return is lower. The results of this study are in line with research conducted by [4] which states that women have a lower risk tolerance level than men. Women value risk stocks higher than men's assessments of stocks so that women rarely trade stocks because of women's riskaverse behavior [12], [23]. This tends to happen in emerging markets [13].

The results of data processing show that $\mathrm{H} 2$ rejected, meaning that there is no significant difference in overconfidence between male and female investors in Aceh. The overconfidence variable produces a mean rank value for males of 192.92 while the mean rank for females is 192.92. This shows that overconfidence behavior in women is greater than in men. These results indicate that the ease of access to information about investments is obtained by every investor, both male and female in Aceh, especially through social media. This also shows that the level of financial ability and knowledge of women's investment products in Aceh is 
quite good so that the overconfidence behavior of women is not significantly different from that of male investors in Aceh. Advances in information technology, education level, knowledge and financial security that make gender differences are no longer a barrier to feeling more confident and brave in making investment decisions. When people believe in their skills or knowledge, they become more willing to follow their own judgment, which can lead to one of the cognitive lapses of overconfidence when investing.

Finally, the results of data processing show that $\mathrm{H} 3$ is accepted, which means that there are significant differences in herding between male and female investors in Aceh. The herding variable produces a mean rank value for males of 176.74 while the mean rank for females is 223.95. This shows that herding behavior in women is greater than in men. The results also show that the mean rank for the herding variable for female investors is higher than for male investors in Aceh. This shows that the behavior of women in Aceh tends to quickly follow the changing trends around them, including in choosing assets to invest. Female investors are more likely to follow the actions of other investors in making investment decisions. The information they get from their relatives or trusted parties will quickly change their investment decisions. Female investors also tend to engage in herding behavior when making investment decisions, especially in developing markets [24]. Investors prefer to do herding when they believe that herding can help them to obtain useful and reliable information. Meanwhile, men who tend to be more independent. This trait makes them more confident to consider their own opinions in making investment decisions.

\section{CONCLUSION}

Based on the results of the research and discussion that have been described, it shows that there are significant differences herding behaviour and risk tolerance between male and female investors in Aceh. The level of risk tolerance in men is higher because of the high optimism and masculine traits possessed by men. This makes them more willing to invest in riskier stocks. Meanwhile, on average, women in Aceh prefer to invest in stocks with lower fluctuations. In addition, female investors in Aceh also tend to prefer to invest in fixed assets such as gold and deposits with a lower average volatility.

Furthermore, the results also show that there is no significant difference in overconfidence behavior between male and female investors in Aceh. Advances in information technology, education level, knowledge and financial security that make gender differences are no longer a barrier to feeling more confident and brave in making investment decisions.

Finally, the research results also show that significant differences between male and female investors in Aceh. The results also show that the mean rank for the herding variable for female investors is higher than for male investors in Aceh. This shows that the behavior of women in Aceh tends to quickly follow the changing trends around them, including in choosing assets to invest. Female investors are more likely to follow the actions of other investors in making investment decisions. The information they get from their relatives or trusted parties will quickly change their investment decisions.

It is essential for investors to consider relevant information in making investment decisions in order to gain optimal profits. In addition, risk tolerance, overconfidence and herding behavior may potentially affect investment performance. The Indonesia Stock Exchange and securities companies can support and work together to provide capital market information, facilities and infrastructure for investment galleries spread across universities in Aceh to improve investment performance of investors in Aceh. Investment galleries in Aceh in order to facilitate the academic world as a medium for early introduction to the capital market so that they can build human resources who have good financial literacy and capital market literacy, are trained, and have optimism, as well as direct involvement in improving the economy through the capital market. In future research, it is suggested to add other variables to observe investor behavior and use different analytical methods to see the effect of investor behavior on investment decisions. In addition, further research is recommended to use different sampling techniques such as cluster random sampling based on area or region to obtain more accurate results in observing investor behavior.

\section{ACKNOWLEDGMENTS}

The authors express their gratitude and highest appreciation to the Dean of the Faculty of Economics, Syiah Kuala University, the Chair and Secretary and staff of the Institute for Research and Community Service (LPPM) at Syiah Kuala University, investors who have become respondents in this research, members of the research team and all parties that I cannot mention one by one here who helped make this research successful. In addition, my family, especially my husband and children, who gave their prayers and patience in supporting me to carry out this research.

\section{REFERENCES}

[1] A. Sakir, U. Salim, and Djumahir, "2017 Perilaku Investor Asing Dan Investor Domestik: Sebuah 
Sintesa Bias Perilaku Dalam Behavioral Finance," FEB Unikama, pp. 304-315, 2017.

[2] M. Asri, Keuangan Keperilakuan. Yogyakarta: BPFE, 2013.

[3] M. Kufepaksi, Perilaku Penipuan Diri Di Bursa Saham. Yogyakarta: Expert, 2016.

[4] O. Badunenko, N. Barasinska, and D. Schäfer, "Is Gender a Good Predictor of Financial Risk Taking? Evidence from National Surveys of Household Finance," JIBS Work. Pap., pp. 1-32, 2010.

[5] M. Merli and T. Roger, "of Individual Investors ?," Finance, vol. 34, no. 3, pp. 67-104, 2013.

[6] M. A. Rahman, S. S. H. Chowdhury, and M. Shibley Sadique, "Herding where retail investors dominate trading: The case of Saudi Arabia," $Q$. Rev. Econ. Financ., vol. 57, pp. 46-60, Aug. 2015, doi: 10.1016/J.QREF.2015.01.002.

[7] B. Jamshidinavid, M. Chavoshani, and S. Amiri, "The Impact of Demographic and Psychological Characteristics on the Investment Prejudices in Tehran Stock," Eur. J. Bus. Soc. Sci., vol. 1, no. 5, pp. 41-53, 2012.

[8] S. Choi, "Herding among local individual investors: Evidence from online and offline trading," Econ. Lett., vol. 144, pp. 4-6, Jul. 2016, doi: 10.1016/J.ECONLET.2016.04.030.

[9] R. Gibson, D. Michayluk, and G. Van de Venter, "Financial risk tolerance: An analysis of unexplored factors," Financ. Serv. Rev., vol. 22, no. 1, pp. 23-50, 2013

[10] G. Charness and U. Gneezy, "Strong Evidence for Gender Differences in Risk Taking," J. Econ. Behav. Organ., vol. 83, no. 1, pp. 50-58, Jun. 2012, doi: 10.1016/J.JEBO.2011.06.007.

[11] L. Le, Phuoc and H. Doan, Thi, Thu, "Behavioral Factors Full Text Thesis," 2011.

[12] P. J. Fisher and R. Yao, "Gender differences in financial risk tolerance," J. Econ. Psychol., vol. 61, pp. 191-202, Aug. 2017, doi: 10.1016/J.JOEP.2017.03.006.

[13] M. Statman, "What Is Behavioral Finance? Putting It in Context," Behav. Financ. Invest. Manag., vol. II, no. 1, pp. 1-12, 2010.

[14] R. Salem, "Examining the investment behavior of Arab women in the stock market," J. Behav. Exp. Financ., vol. 22, pp. 151-160, Jun. 2019, doi: 10.1016/J.JBEF.2019.03.001.

[15] T. R. Hassan, W. Khalid, and A. Habib, "Overconfidence and loss aversion in investment decisions : A study of the impact of gender and age in Pakistani perspective," Res. J. Financ. Account. www.iiste.org ISSN, vol. 5, no. 11, pp. 148-158, 2014.

[16] A. O. I. Hoffmann and T. Post, "How does investor confidence lead to trading? Linking investor return experiences, confidence, and investment beliefs," $J$. Behav. Exp. Financ., vol. 12, pp. 65-78, 2016, doi: 10.1016/j.jbef.2016.09.003.

[17] D. W. Alrabadi, M. A. Al-Gharaibeh, and M. Z. Ziad, "What makes investors overconfident? evidence from amman stock exchange," Eur. J. Econ. Financ. Adm. Sci., vol. 43, no. 43, pp. 28-34, 2011.

[18] M. I. M. Alnajjar, "Behavioral Inferences of Tadawul Investor," Int. J. Bus. Manag., vol. 8, no. 24, pp. 17-24, 2013, doi: 10.5539/ijbm.v8n24p17.

[19] L. Sullivan, "Nonparametric Tests," Boston University School of Public Health, 2016.

[20] D. Kourtidis, Ž. Šević, and P. Chatzoglou, "Investors' trading activity: A behavioural perspective and empirical results," J. Socio. Econ., vol. 40, no. 5, pp. 548-557, Oct. 2011, doi: 10.1016/J.SOCEC.2011.04.008.

[21] Sugiyono, Metode Penelitian Pendidikan Pendekatan Kuantitatif, Kualitatif, dan R\&D. Bandung: Alfabeta, 2014.

[22] A. J. Vickers, "Parametric versus non-parametric statistics in the analysis of randomized trials with non-normally distributed data," BMC Med. Res. Methodol., vol. 5, pp. 1-12, 2005, doi: 10.1186/1471-2288-5-35.

[23] Y. J. Lee, G. L. Wang, K. S. Kao, C. Y. Chen, and F. P. Zhu., "The Investment Behavior, Decision Factors And Their Effects Toward Investment Performance In The Taiwan Stock Market," $J$ Glob. Bus. Manag., vol. 6, no. 2, pp. 1-12, 2010.

[24] H. Lin, "Elucidating rational investment decisions and behavioral biases: Evidence from the Taiwanese stock market," African J. Bus. Manag., vol. 5, no. 5, pp. 1630-1641, 2011, doi: 10.5897/AJBM10.474 